\title{
In Vitro and In Vivo Activation of Endothelial Cells by Colony-stimulating Factors
}

Federico Bussolino," Marina Ziche, ${ }^{\ddagger}$ J. Ming Wang, Daniela Alessi," Lucia Morbidelli, Ottavio Cremona," Amalia Bosia," Pier Carlo Marchisio," and Alberto Mantovani"

*Dipartimento di Genetica, Biologia, e Chimica Medica, and "Dipartimento di Scienze Biomediche e Oncologia Umana, Università di Torino, 10126 Torino, Italy; ${ }^{\circ}$ Dipartimento di Farmacologia Preclinica e Clinica "Mario Aiazzi Mancini", Università di Firenze, 50134 Firenze, Italy; and \$Istituto di Ricerche Farmacologiche "Mario Negri", 20157 Milano, Italy

\begin{abstract}
This study was designed to identify the set of functions activated in cultured endothelial cells by the hematopoietic growth factors, granulocyte colony-stimulating factor (G-CSF) and granulocyte macrophage-colony-stimulating factor (GMCSF), and to compare them with those elicited by prototypic cytokines active on these cells. Moreover, indications as to the in vivo relevance of in vitro effects were obtained. G-CSF and GM-CSF induced endothelial cells to proliferate and migrate. In contrast, unlike appropriate reference cytokines (IL-1 and tumor necrosis factor, IFN- $\gamma$ ), G-CSF and GM-CSF did not modulate endothelial cell functions related to hemostasisthrombosis (production of procoagulant activity and of platelet activating factor), inflammation (expression of leukocyte adhesion molecule-1 and production of platelet activating factor), and accessory function (expression of class II antigens of MHC). Other colony-stimulating factors (IL-3 and macrophage-colony-stimulating factor) were inactive on all functions tested. In comparison to basic fibroblast growth factor (bFGF), G-CSF and GM-CSF induced lower maximal proliferation of endothelial cells, whereas migration was of the same order of magnitude. G-CSF and GM-CSF stimulated repair of mechanically wounded endothelial monolayers. Exposure to both cytokines induced shape changes and cytoskeletal reorganization consistent with a migratory phenotype. To explore the in vivo relevance of the in vitro effects of these cytokines on endothelium, we studied the angiogenic activity of human G-CSF in the rabbit cornea. G-CSF, but not the heat-inactivated molecule, had definite angiogenic activity, without any sign of inflammatory reactions. G-CSF was less active than bFGF. However, the combination of a nonangiogenic dose of bFGF with G-CSF resulted in an angiogenic response higher than that elicited by either individual cytokines. Thus, G-CSF and GM-CSF induce endothelial cells to express an activation/differentiation program (including proliferation and migration) related to angiogenesis. (J. Clin. Invest. 1991. 87:986-995.) Key words: angiogenesis • chemotaxis • cellular growth • cytokines • colonystimulating factors
\end{abstract}

Address reprint requests to Dr. F. Bussolino, Dipartimento di Genetica Biologia e Chimica Medica, Via Santena 5 bis, 10126 Torino, Italy. 1990.

Received for publication 15 May 1990 and in revised form 4 October

J. Clin. Invest.

(C) The American Society for Clinical Investigation, Inc.

0021-9738/91/03/0986/10 \$2.00

Volume 87, March 1991, 986-995

\section{Introduction}

A family of glycoprotein molecules, termed colony-stimulating factors (CSF), ${ }^{1}$ control proliferation, maturation, and functional activities of granulocytes, macrophages, and their precursors (1-3). Granulocyte (G)- and granulocyte-macrophage (GM)-CSF regulate cells belonging to the myelomonocytic differentiation pathway. Until recently, G- and GM-CSF were considered growth and differentiation factors with a spectrum of action restricted to the hematopoietic system (1-3). Recent evidence indicates that nonhematopoietic elements, including solid tumor lines (4-6), bone marrow fibroblasts (4), and keratinocytes (7) respond to G- and GM-CSF. We have shown that human endothelial cells derived from umbilical vein (HUVEC) and a human endothelial hybrid cell line (EAhy926) have high affinity receptors for G- and GM-CSF (8), similar in number and affinity to those present on myelo-monocytic cells (1-3). Unlike myelo-monocytes and endothelial cells, other cell types studied in this respect have low affinity GM-CSF receptors $(5,9)$.

After binding to their receptors on HUVEC, G- and GMCSF start sequential early events, including a rise of intracellular $\mathrm{pH}(10)$ and expression of the c-fos protooncogene (8), followed by cell migration and proliferation $(8,10)$. G-CSFtreated bovine endothelial cells also release plasminogen activator (11), an event commonly associated with migration (12). Thus, G- and GM-CSF are among the cytokines that modulate the functional status of endothelial cells (13-15).

Cytokine-elicited endothelial cell responses follow distinct, largely nonoverlapping, differentiation/activation programs (15). IL-1 and tumor necrosis factor (TNF) induce proinflammatory/prothrombotic changes in endothelial cells. These include production of procoagulant activity (PCA) (16-19), prostaglandins $(20,21)$, platelet-activating factor (PAF) $(22,23)$, and plasminogen activator inhibitor (24), inhibition of plasminogen activator synthesis (24), alterations in the thrombomodulin/protein $C$ anticoagulation pathway $(19,25)$, expression of endothelial-leukocyte adhesion molecule-1 (ELAM-1) $(26,27)$, and upregulation of intercellular adhesion molecule-1 $(28,29)$. IFN- $\gamma$ induces class II antigens of MHC in endothelial cells $(30,31)$, a crucial determinant of accessory cell function.

1. Abbreviations used in this paper: bFGF, basic FGF; CSF, colonystimulating factor; ELAM-1, endothelial-leukocyte molecule adhesion 1; FGF, fibroblast growth factor; G-CSF, granulocyte-CSF; GM-CSF, granulocyte-macrophage-CSF; $\left[{ }^{3} \mathrm{H}\right] \mathrm{Tdr},\left[{ }^{3} \mathrm{H}\right]$ thymidine; HUVEC, endothelial cells from human umbilical vein; M-CSF, macrophage-CSF; PAF, platelet-activating factor; PCA, procoagulant activity; R-PHD, rhodamine-labeled phalloidin; TNF, tumor necrosis factor. 
Finally, fibroblast growth factors (FGF) $(32,33)$, transforming growth factors $(34,35)$, and epidermal growth factor (36) control functions (proliferation and migration) related to angiogenesis.

The aim of this study was to characterize the set of endothelial cell functions modulated by G- and GM-CSF and to compare these cytokines with prototypic polypeptide mediators active on endothelium (IL-1 and TNF, IFN- $\gamma$, basic-FGF). Furthermore, we searched for indications as to whether the in vitro effects of G- and GM-CSF (i.e., induction of migration and proliferation) have in vivo relevance.

\section{Methods}

Cytokines. Human recombinant cytokines and their sources were as follows: G-CSF $\left(5 \times 10^{7} \mathrm{U} / \mathrm{mg}\right.$ protein $)$, GM-CSF $\left(1 \times 10^{7} \mathrm{U} / \mathrm{mg}\right.$ protein), and IL-3 $\left(1 \times 10^{7} \mathrm{U} / \mathrm{mg}\right.$ protein $)$ from Dr. D. Krumwieh, Behringwerke, Marburg, FRG; M-CSF $\left(4 \times 10^{7} \mathrm{U} / \mathrm{mg}\right.$ protein $)$ and TNF $\alpha\left(1 \times 10^{6} \mathrm{U} / \mathrm{mg}\right.$ protein $)$ from Dr. P. Ralph, Cetus Corp., Emeryville, CA; basic-FGF (bFGF) from Farmitalia, Milano, Italy; IFN- $\gamma(1$ $\times 10^{6} \mathrm{U} / \mathrm{mg}$ protein $)$ from Biogen, Geneva, Switzerland; IL- $1 \alpha\left(1 \times 10^{8}\right.$ $\mathrm{U} / \mathrm{mg}$ protein) from Immunex, Seattle, WA. G- and GM-CSF were neutralized by incubation at $37^{\circ} \mathrm{C}$ for $40 \mathrm{~min}$ with mouse monoclonal antibody anti-human G-CSF (a gift of Dr. L. Souza, Amgen Biologicals, Thousand Oaks, CA) or with rabbit polyclonal antibody anti-human GM-CSF (a gift of Dr. S. Clark, Genetic Institute, Cambridge, MA), as described (8).

Cell cultures. HUVEC were grown in M199 supplemented with 20\% FCS (Gibco Laboratories, Grand Island, NY), endothelial cell growth factor ( $100 \mu \mathrm{g} / \mathrm{ml}$, Sigma Chemical Co., St. Louis, MO) and porcine heparin $(100 \mu \mathrm{g} / \mathrm{ml}$, Sigma) and used at early passages (I-IV). No leukocyte contamination was observed by FACS analysis of cells stained with monoclonal antibodies anti-CD11b, Mo2, and $\mathrm{T}_{3}(8$, 10, 22).

Proliferation assay. $2 \times 10^{4}$ HUVEC were plated in 24-well plates (Costar Data Packaging Corp., Cambridge, MA), coated with gelatin (Difco Laboratories Inc., Detroit, $\mathrm{MI})\left(0.05 \%\right.$, for $1 \mathrm{~h}$ at $\left.22^{\circ} \mathrm{C}\right)$, and grown for $24 \mathrm{~h}$ in M199 containing 20\% FCS. Medium was then removed and replaced with M199 containing 10\% FCS with or without cytokines. HUVEC number was estimated after $4 \mathrm{~d}$ by fluorimetric DNA assay using a DNA intercalating fluorescent compound, bisbenzimide (Sigma), as previously described (10).

For experiments of $\left[{ }^{3} \mathrm{H}\right]$ thymidine $\left(\left[{ }^{3} \mathrm{H}\right] \mathrm{TdR}\right)$ incorporation, 2 $\times 10^{4}$ cells were plated in 6 -well $(35-\mathrm{mm}$ diameter) plate dishes coated for $24 \mathrm{~h}$ with gelatin $(0.05 \%$, Difco), and processed as previously described (8). Briefly, the cells were grown for $24-36 \mathrm{~h}$ in M199 with $20 \%$ FCS and then starved for $48 \mathrm{~h}$ in $1 \%$ FCS with $0.5 \%$ BSA (fraction V, Sigma). Medium was then removed and replaced with control medium containing $2 \%$ FCS with or without G-, GM-CSF, or bFGF. The cells were incubated for $11 \mathrm{~h}$ at $37^{\circ} \mathrm{C},\left[{ }^{3} \mathrm{H}\right] \mathrm{TdR}(0.5 \mu \mathrm{Ci}, 30 \mathrm{Ci} / \mathrm{mmol}$; Amersham International, Amersham, Bucks, UK) was added and incubation continued for $6 \mathrm{~h}$. Medium was removed, cells were washed twice with cold PBS, and detached by trypsinization. DNA was precipitated with $10 \%$ cold TCA and collected on $0.2-\mu \mathrm{m}$ filters (GS type; Millipore Corp., Milano, Italy). Radioactivity was measured by liquid scintillation counting.

Chemotaxis assay. Chemotaxis assays were performed in 48-well modified Boyden chambers $(8,37,38)$, using polycarbonate filters (5$\mu \mathrm{m}$ pore size, polyvinylpyrrolidone-free, Nuclepore Corp., Pleasanton, CA) coated with gelatin. Cytokines in M199 containing 1\% FCS were seeded in the lower compartments of the chamber, and $1 \times 10^{5}$ suspended HUVEC in M199 containing 1\% FCS were then seeded in the upper compartments. After $6 \mathrm{~h}$ of incubation at $37^{\circ} \mathrm{C}$, the upper surface of the filter was scraped with a rubber policeman. The filters were fixed and stained with Diff-Quick (Harleco, Gibbstown, NJ), and 10 oil immersion microscopic fields were counted after coding samples.
Wound assay and fluorescence microscopy studies. HUVEC were grown at confluency on glass coverslips coated with human fibronectin $\left(10 \mu \mathrm{g} / \mathrm{ml}\right.$, Sigma, for $1 \mathrm{~h}$ at $\left.22^{\circ} \mathrm{C}\right)$ for fluorescence studies or on 24-well plates coated in the same way. The monolayer was wounded with a razor blade. After wounding, cells were washed with PBS and incubated in M199 containing 10\% FCS in the presence of different cytokines. For fluorescence studies, coverslip-attached HUVEC were fixed with $3 \%$ isotonic formaldehyde solution, $\mathrm{pH} 7.6$, containing $2 \%$ sucrose, and permeabilized by Triton X-100 buffer ( 20 mM Hepes, 300 $\mathrm{mM}$ sucrose, $50 \mathrm{mM} \mathrm{NaCl}, 3 \mathrm{mM} \mathrm{MgCl}{ }_{2}, 0.5 \%$ Triton X-100, $\mathrm{pH} 7.4$ ) (39). HUVEC were stained with rhodamine-labeled phalloidin ( $R$ PHD, Sigma). Alternatively, HUVEC were incubated with an antivinculin monoclonal antibody (Vin 11-5; Bio-Makor, Rehovot, Israel), rinsed extensively with PBS, and then stained with rhodamine-tagged rabbit anti-mouse IgG and with fluorescein-labeled phalloidin (39). Coverslips, mounted in 50\% PBS-glycerol, were observed in an Axiophot microscope (Zeiss, Oberkochen, FRG) equipped for epifluorescence. Fluorescence images were recorded on Kodak T-Max films exposed at 1,000 ISO (International Standard Organization) and developed for $10 \mathrm{~min}$ at $20^{\circ} \mathrm{C}$ in T-Max developer.

To quantify the cells migrated in the denuded area, HUVEC grown on plastic wells were fixed with absolute methanol $(5 \mathrm{~min}$ at room temperature) and stained with Giemsa staining solution. Samples were coded and cells migrated from the edge of the wound were counted in successive $100-\mu \mathrm{m}$ increments at $\times 100$ using an inverted light microscope (IM35; Zeiss) provided with an ocular grid eyepiece (40).

$P A F$ production. HUVEC grown on $35-\mathrm{mm}$ wells were stimulated in M199 containing $0.25 \%$ BSA. At the end of incubation, the medium was removed and cells were scraped with a rubber policeman in $1 \mathrm{ml}$ methanol containing formic acid to lower pH to 3.0 (22). Extracted PAF was purified by thin layer chromatography, characterized by chromatographic and physico-chemical criteria and treatment with lipases, and quantified by aggregation of washed rabbit platelets, as previously described $(22,41)$.

Standard incubation time for PAF production was $6 \mathrm{~h}$ at $37^{\circ} \mathrm{C}$. This time point was selected on the basis of preliminary time-course experiments (from $5 \mathrm{~min}$ to $24 \mathrm{~h}$ ).

$P C A$ assay. HUVEC monolayers on gelatin-coated wells $(16 \mathrm{~mm}$ diameter) were stimulated for $4 \mathrm{~h}$ at $37^{\circ} \mathrm{C}$ in M199 containing $10 \%$ FCS, and then extensively rinsed with M199. After five freezing and thawing cycles, total cellular PCA was determined in a one-stage clotting assay, using glass tubes containing $0.1 \mathrm{ml}$ human pooled citrated plasma, to which $0.1 \mathrm{ml}$ cell extract and $0.1 \mathrm{ml} 30 \mathrm{mM} \mathrm{CaCl}_{2}$ solution were added. Milliunits ( $\mathrm{mU}$ ) of PCA were calculated according to Bevilacqua et al. (16). In our standard conditions $10^{3} \mathrm{mU}$ PCA corresponded to a clotting time of $23 \mathrm{~s}$. The incubation time was selected on the basis of preliminary time-course experiments.

Study of the surface expression of ELAM-1, and class II MHC antigens (HLA-Dr). Unstimulated HUVEC and HUVEC cytokine-stimulated for the indicated time were detached from the gelatin-coated wells by incubation with $5 \mathrm{mM}$ EGTA (Sigma) and $1 \%$ BSA in PBS, pH 7.4, for $10 \mathrm{~min}$ at $37^{\circ} \mathrm{C}$. Suspended HUVEC were stained with monoclonal antibody anti-class II (AA3.84) (a gift of Dr. F. Malavasi, Dipartimento di Genetica, Biologia e Chimica Medica, Torino, Italy) (42), or antiELAM-1 (H1/6, a gift of Dr. M. Bevilacqua, Harvard University, Boston, MA) (26), and then with fluorescein-tagged rabbit anti-mouse IgG (Technogenetics, Torino, Italy). Stained cells $\left(1 \times 10^{4}\right)$ were analyzed by FACS. Background nonspecific staining was determined with $\times 63$, irrelevant murine myeloma protein (a gift of Dr. F. Malavasi).

In vivo angiogenic assay. G-CSF (10-100 ng), G-CSF boiled for 10 $\min (50-100 \mathrm{ng})$, and bFGF (1-50 ng) were incorporated into a slow release vinyl copolymer (Elvax 40; DuPont Co., Wilmington, DE) to produce $1 \times 1 \times 0.5-\mathrm{mm}$ size pellets. Pellets were prepared in sterile conditions as follows: evaporated cytokines were resuspended into a casting solution of $10 \%$ Elvax-40 in methylene chloride ( $10 \mu \mathrm{l} / \mathrm{droplet})$ and allowed to evaporate. The repolymerized pellets were further evaporated at $4^{\circ} \mathrm{C}$ overnight. The angiogenic assay was performed using corneas of adult outbred New Zealand rabbits weighing 2-3 kg (43). In 
the lower corneal half of anesthetized animals (pentobarbital, 25-30 $\mathrm{mg} / \mathrm{kg}$ ) pockets were produced into half of the thickness of the corneal stroma using a pliable iris spatula $1.5 \mathrm{~mm}$ in width. The bottom of each pocket was kept at $2 \mathrm{~mm}$ from the limbal vessel. Elvax -40 pellets were placed into the preformed corneal pockets. In some experiments, the standard protocol was modified by producing two adjacent pockets, 2 $\times 3 \mathrm{~mm}$ each, as previously reported (44). Subsequent daily observations of the implants were made with a slit lamp stereomicroscope without anesthesia. An angiogenic response was considered valid when budding of vessels from the limbal plexus occurred at 3-4 $d$ and persisted for at least 2 wk from the surgical implant. Angiogenesis was expressed as the number of implants exhibiting neovascularization of normally avascular corneal stroma over the total implants performed. Neovascularization was also recorded and scored by the number of newly formed vessels and by their growth rate. An arbitrary five point ordinal scale ranging from 0 to 4 was used to quantify the potency of the angiogenic response on the basis of the number of newly formed vessels produced by the tested compounds: 0 , no vessel growth; $1+$, equivocal vessel growth from the limbus to $0.6 \mathrm{~mm}$ over the limbus; $2+$, evident new vessel formation extending midway to the corneal pocket; $3+$, prominent new vessel formation reaching the corneal pocket; $4+$, extensive neovascularization extending into the corneal pocket and surrounding the implant. The occurrence of an inflammatory reaction accompanying neovascularization was also investigated at macroscopic level by scoring the presence of corneal opacity and at microscopic level by histological examination of the corneal explants obtained after 3-12 d of observation. Corneal explants were fixed by immersion in $10 \%$ phosphate-buffered formalin. Serial paraffin $(7-\mu \mathrm{m}$ sections) were stained with hematoxylin and eosin.

\section{Results}

Effects of G- and GM-CSF on HUVEC in relation to prototypic cytokines. A major objective of this study was to define the set of responses elicited by G- and GM-CSF in HUVEC and to compare it with prototypic cytokines active on these cells. We examined functions related to thrombosis and inflammation (PCA, PAF, expression of leukocyte adhesion structures, such as ELAM-1), to accessory activity (HLA-Dr antigens), to angiogenesis (proliferation and migration). IL- $1 \alpha / \mathrm{TNF} \alpha$, IFN- $\gamma$, and bFGF served as reference cytokines which activate HUVEC for distinct sets of functions. As shown in Table I, G- and
GM-CSF induced migration and proliferation of HUVEC, but failed to affect all other parameters examined. Table I summarizes the results obtained at one concentration $(100 \mathrm{ng} / \mathrm{ml})$ of G- and GM-CSF, respectively, and for one exposure time, optimal for the parameters and reference cytokines examined (see legend to Table I and Methods). For instance, PCA was measured at $4 \mathrm{~h}$, when maximal stimulation of HUVEC by IL- $1 \alpha$ $(10 \mathrm{ng} / \mathrm{ml})$ and TNF $\alpha(10 \mathrm{ng} / \mathrm{ml})$ is observed (Table I and 16 , 18). It must be emphasized that a range of concentrations of Gand GM-CSF (from 0.1 to $500 \mathrm{ng} / \mathrm{ml}$ ) and exposure times (from 2 to $72 \mathrm{~h}$ ) were studied (not shown) with results consistent with those selected for display in Table I. Thus, G- and GM-CSF induced migration and proliferation of HUVEC without affecting functions related to inflammation, thrombosis, and accessory activity. When compared with the cytokine selected as reference agent for migration and proliferation (bFGF), the maximal proliferative response elicited by CSFs was substantially less (Table I and Fig. $1 A$ ). In a series of experiments $(n=10)$, G-, GM-CSF, and bFGF caused 1.5-fold (range 1.2-5), 1.5-fold (range 1.15-3.1), and 2.2-fold (range 2-8) increment of proliferation, respectively. CSFs-induced HUVEC migration was of the same order of magnitude as that induced by bFGF (Table I and Fig. $1 B$ ).

We also examined the effect of combined exposure of $\mathrm{HU}$ VEC to CSFs and bFGF. Fig. 2 presents two experiments out of ten performed with G-CSF. Similar results were obtained with GM-CSF (not shown). No evidence of synergism was obtained in terms of proliferation and migration using both optimal and suboptimal concentrations of the two cytokines. At most, an additive effect was observed, particularly in the migration assay (Fig. $2 \mathrm{~B}$ ), or in the proliferation assay with suboptimal concentrations of G-CSF (Fig. $2 A$ ). The combination of optimal concentrations of G-CSF with bFGF resulted in an inhibitory effect on proliferation (Fig. $2 \mathrm{~A}$ ). The experiment summarized in Fig. 2 was performed with simultaneous exposure to the two cytokines. No reciprocal potentiation was also observed when HUVEC were exposed to G- or GM-CSF for $24 \mathrm{~h}$ and then examined for responsiveness to bFGF in terms of migration and proliferation, and vice versa (not shown). It was of interest

Table I. In Vitro Effects of G- and GM-CSF on HUVEC in Comparison to Prototypic Cytokines*

\begin{tabular}{lccccccc}
\hline \multicolumn{1}{c}{ Cytokines } & \multicolumn{1}{c}{ PAF $^{*}$} & PCA & ELAM-1 & HLA-Dr & \multicolumn{2}{c}{ Proliferation } & Migration \\
\hline & $p m o l / 1 \times 10^{5}$ cells & $m U / 1 \times 10^{5}$ cells & \multicolumn{2}{c}{$\%$ positive } & Cells $1 \times 10^{4}$ & {$\left[^{3}\right.$ H]TdR cpm $1 \times 10^{3}$} & Cells in six fields \\
None & $0.3 \pm 0.1$ & $8 \pm 4$ & 0 & $0-3$ & $23.3 \pm 1.2$ & $1.1 \pm 0.3$ & $25 \pm 3$ \\
G-CSF $100 \mathrm{ng} / \mathrm{ml}$ & $0.3 \pm 0.2$ & $13 \pm 5$ & $0-2$ & $0-5$ & $36.1 \pm 3.1$ & $15.8 \pm 2.1$ & $67 \pm 2$ \\
GM-CSF $100 \mathrm{ng} / \mathrm{ml}$ & $0.2 \pm 0.1$ & $10 \pm 4$ & $0-3$ & $1-6$ & $34.2 \pm 1.9$ & $16.2 \pm 2.6$ & $71 \pm 3$ \\
bFGF $5 \mathrm{ng} / \mathrm{ml}$ & NT & NT & NT & NT & $51.4 \pm 3.8$ & $46.3 \pm 5.1$ & $80 \pm 5$ \\
IFN- $\gamma 500 \mathrm{ng} / \mathrm{ml}$ & NT & NT & NT & $45-69$ & NT & NT & NT \\
IL- $1 \alpha 10 \mathrm{ng} / \mathrm{ml}$ & $1.9 \pm 0.2$ & $106 \pm 17$ & $55-67$ & NT & NT & NT & NT \\
TNF $\alpha 10 \mathrm{ng} / \mathrm{ml}$ & $2.1 \pm 0.5$ & $119 \pm 28$ & $51-63$ & NT & NT & NT & NT
\end{tabular}

* HUVEC were stimulated with different cytokines and processed for the different tests as described in Methods. The numbers are mean \pm SD of 3-10 experiments done in triplicate. The data shown for the expression of ELAM-1 and class II MHC antigens (HLA-Dr) are the range of a quadruplicate culture of one experiment of two performed with similar results. The data presented refer to the exposure time at which the appropriate reference cytokine is active on each parameter. Specifically, exposure times were: $6 \mathrm{~h}$ for PAF; $4 \mathrm{~h}$ for PCA and ELAM-1; $3 \mathrm{~d}$ for expression of HLA-Dr antigen; $4 \mathrm{~d}$ (cell count) or $11 \mathrm{~h}\left[{ }^{3} \mathrm{H}\right] \mathrm{TdR}$ ) for proliferation; $6 \mathrm{~h}$ for migration. ${ }^{\ddagger}$ Since HUVEC can produce PAF within a few minutes of thrombin stimulation (51), PAF synthesis was also measured after $5 \mathrm{~min}$ stimulation with G-CSF and GM-CSF (100 ng/ml) or thrombin $\left(0.5 \mathrm{U} / \mathrm{ml}\right.$, Sigma) with the following results (pmol/10 $10^{5}$ cells): control, $0.2 \pm 0.1$; G-CSF, $0.3 \pm 0.2$; GM-CSF, $0.4 \pm 0.3$; thrombin, 2.8 \pm 0.6 . NT, not tested. 

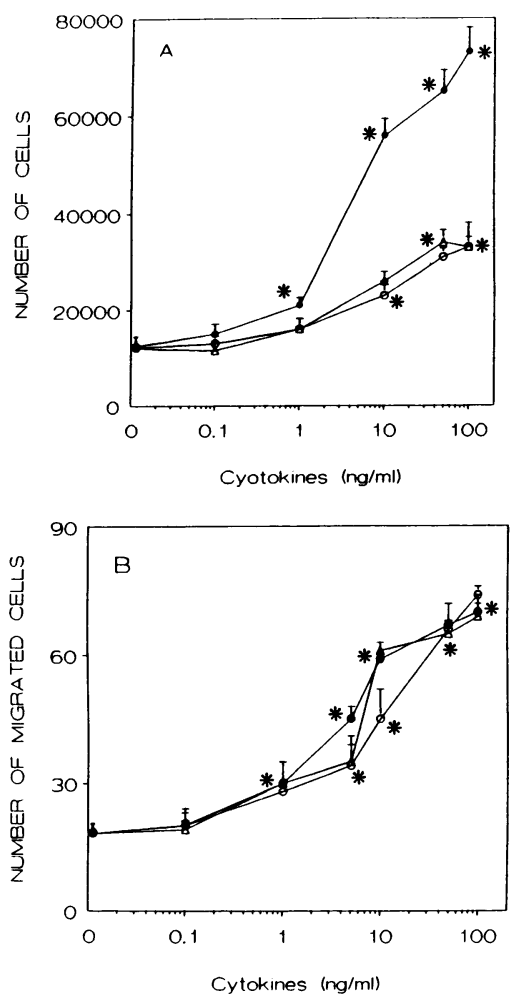

Figure 1. Effect of different doses of G$\operatorname{CSF}(\triangle)$, GM-CSF (o), and bFGF $(\bullet)$ on proliferation $(A)$ and migration $(B)$ of HUVEC. For proliferation assay, low density cultures of HUVEC $\left(1 \times 10^{4}\right.$ cells per $22 \mathrm{~mm}$ diameter gelatinized tissue culture well) were exposed to M199 supplemented with $10 \%$ FCS containing different concentrations of cytokines. After $4 \mathrm{~d}$, cells were counted $(6$ wells for each point) as described in Methods. The numbers are the mean \pm SD of six determinations. For migration assay, 48-well modified Boyden chambers were used, as described in Methods. Cytokines in M199 containing $1 \%$ FCS were seeded in the lower compartment of the chamber, and $1 \times 10^{5}$ HUVEC in the same medium were seeded in the upper compartments. Cells migrated after $6 \mathrm{~h}$ incubation to the lower surface of the filter were counted after coding samples. The numbers are the mean \pm SD of six fields counted. The data shown are representative of one experiment for each assay out of 11 done with similar results. $P<0.05$ by Student's $t$ test. In $A$ some asterisks were omitted to simplify the picture, and those drawn refer to the three cytokines.

to evaluate whether other hematopoietic growth factors shared the ability of G- and GM-CSF to affect HUVEC. As shown in Table II, IL-3 and M-CSF did not affect either the migration and proliferation or the production of PCA and PAF by HUVEC.

Induction of HUVEC monolayer wound repair by $G$ - and $G M-C S F$. The above results indicate that G- and GM-CSF induce proliferation and migration across pores of polycarbonate filters of sparsely seeded HUVEC. It was of interest to evaluate the effect of G- and GM-CSF under conditions that more closely resemble those of the monolayer lining of blood vessels. These experiments were also prompted by a recent report indicating that TNF has different effects on sparse versus confluent endothelial cells (45). We therefore examined the effect of Gand GM-CSF on the repair of a mechanically induced wound of HUVEC monolayers. Fig. 3 illustrates the G-CSF-induced repair of wounded monolayers and Table III presents a quantitative assessment of this activity. The effect of G-CSF in inducing wound repair is time (Fig. 3, $a-d$ ) and dose dependent (Fig. $3, e-h)$. After $6 \mathrm{~h}$ of stimulation with $100 \mathrm{ng} / \mathrm{ml} \mathrm{G}-\mathrm{CSF}$, some cells move into denuded areas (Fig. 3 b), and they almost completely occupy the free space within $24 \mathrm{~h}$. The maximal activity is observed at $100 \mathrm{ng} / \mathrm{ml}$ of G-CSF (Fig. $3 h$ ), whereas it was almost negligible with $0.1 \mathrm{ng} / \mathrm{ml}$ (Fig. $3 e$ ). When HUVEC were treated for $60 \mathrm{~min}$ at $37^{\circ} \mathrm{C}$ with mitomycin $\mathrm{C}(1 \mu \mathrm{g} / \mathrm{ml})$,
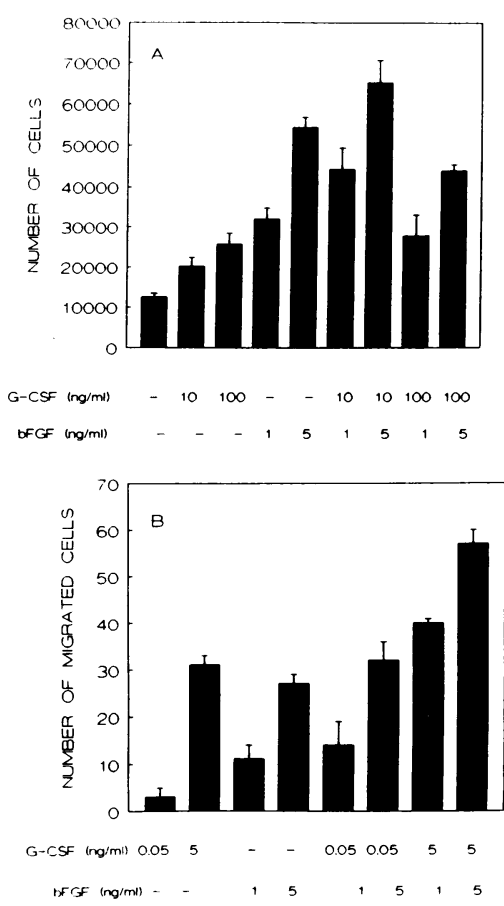

$\mathrm{ng} / \mathrm{ml}$; bFGF, $1 \mathrm{ng} / \mathrm{ml}$ bFGF, $5 \mathrm{ng} / \mathrm{ml}$; G-CSF $10 \mathrm{ng} / \mathrm{ml}+\mathrm{FGF}$ $\mathrm{ng} / \mathrm{ml}$; G-CSF, $10 \mathrm{ng} / \mathrm{ml}+$ bFGF $5 \mathrm{ng} / \mathrm{ml}$; G-CSF, $100 \mathrm{ng} / \mathrm{ml}$ $+\mathrm{bFGF} 1 \mathrm{ng} / \mathrm{ml}$; G-CSF, $100 \mathrm{ng} / \mathrm{ml}+\mathrm{bFGF} 5 \mathrm{ng} / \mathrm{ml} ; \mathrm{bFGF}, 1 \mathrm{ng} / \mathrm{ml}$ vs. bFGF $5 \mathrm{ng} / \mathrm{ml}$; G-CSF $10 \mathrm{ng}+\mathrm{bFGF}, 1 \mathrm{ng} / \mathrm{ml}$; G-CSF, $10 \mathrm{ng} / \mathrm{ml}$ + FGF $1 \mathrm{ng} / \mathrm{ml}$; G-CSF, $100 \mathrm{ng} / \mathrm{ml}+$ bFGF $5 \mathrm{ng} / \mathrm{ml} ; \mathrm{bFGF}, 5 \mathrm{ng} / \mathrm{ml}$ vs. G-CSF $10 \mathrm{ng} / \mathrm{ml}$; G-CSF, $100 \mathrm{ng} / \mathrm{ml}$; G-CSF, $100 \mathrm{ng} / \mathrm{ml}+\mathrm{bFGF}$, $1 \mathrm{ng} / \mathrm{ml}$; G-CSF, $10 \mathrm{ng} / \mathrm{ml}+$ bFGF, $1 \mathrm{ng} / \mathrm{ml}$ vs. G-CSF, $10 \mathrm{ng} / \mathrm{ml}$; G-CSF, $100 \mathrm{ng} / \mathrm{ml}$; G-CSF, $10 \mathrm{ng} / \mathrm{ml}+\mathrm{bFGF}, 5 \mathrm{ng} / \mathrm{ml}$; G-CSF, 100 $\mathrm{ng} / \mathrm{ml}+\mathrm{bFGF}, 1 \mathrm{ng} / \mathrm{ml}$; G-CSF, $10 \mathrm{ng} / \mathrm{ml}+\mathrm{bFGF}, 5 \mathrm{ng}$ vs. G-CSF, $100 \mathrm{ng} / \mathrm{ml}+\mathrm{bFGF}, 1 \mathrm{ng} / \mathrm{ml}$; G-CSF, $100 \mathrm{ng} / \mathrm{ml}+\mathrm{bFGF}, 5 \mathrm{ng} / \mathrm{ml}$. In migration experiments, the following comparisons gave $P<0.05$ by Student-Neuman-Keuls test: G-CSF, $0.05 \mathrm{ng} / \mathrm{ml}$ vs. G-CSF, 5 $\mathrm{ng} / \mathrm{ml}$; bFGF, $0.1 \mathrm{ng} / \mathrm{ml}$; bFGF, $1 \mathrm{ng} / \mathrm{ml}$; G-CSF, $0.05 \mathrm{ng} / \mathrm{ml}$ + bFGF, $0.1 \mathrm{ng} / \mathrm{ml}$; G-CSF, $0.05 \mathrm{ng} / \mathrm{ml}+\mathrm{bFGF}, 1 \mathrm{ng} / \mathrm{ml}$; G-CSF, 5 $\mathrm{ng} / \mathrm{ml}+\mathrm{bFGF}, 0.1 \mathrm{ng} / \mathrm{ml}$; G-CSF, $5 \mathrm{ng} / \mathrm{ml}+\mathrm{bFGF}, 1 \mathrm{ng} / \mathrm{ml} ; \mathrm{G}-\mathrm{CSF}$, $5 \mathrm{ng} / \mathrm{ml}$ vs. bFGF, $0.1 \mathrm{ng} / \mathrm{ml}$; G-CSF, $0.05 \mathrm{ml} / \mathrm{ng}+$ bFGF, $0.1 \mathrm{ng} / \mathrm{ml}$; G-CSF, $5 \mathrm{ng} / \mathrm{ml}+$ bFGF, $1 \mathrm{ng} / \mathrm{ml}$; bFGF, $0.1 \mathrm{ng} / \mathrm{ml}$; bFGF, $1 \mathrm{ng} / \mathrm{ml}$; G-CSF, $5 \mathrm{ng}+$ bFGF, $0.1 \mathrm{ng} / \mathrm{ml}$; G-CSF, $5 \mathrm{ng} / \mathrm{ml}+$ bFGF, 0.1 $\mathrm{ng} / \mathrm{ml}$; G-CSF, $5 \mathrm{ng} / \mathrm{ml}+\mathrm{bFGF}, 1 \mathrm{ng} / \mathrm{ml}$; bFGF, $1 \mathrm{ng} / \mathrm{ml}$ vs. G-CSF, $0.05 \mathrm{ng} / \mathrm{ml}+\mathrm{bFGF}, 0.1 \mathrm{ng} / \mathrm{ml}$; G-CSF, $0.05 \mathrm{ng} / \mathrm{ml}+\mathrm{bFGF}, 1 \mathrm{ng} / \mathrm{ml}$; G-CSG, $5 \mathrm{ng} / \mathrm{ml}+$ bFGF, $0.1 \mathrm{ng} / \mathrm{ml}$; G-CSF, $5 \mathrm{ng} / \mathrm{ml}+$ bFGF, 1 $\mathrm{ng} / \mathrm{ml}$; G-CSF, $0.05 \mathrm{ng} / \mathrm{ml}+\mathrm{bFGF}, 0.1 \mathrm{ng} / \mathrm{ml}$ vs. G-CSF, $0.05 \mathrm{ng} / \mathrm{ml}$ + bFGF, $1 \mathrm{ng} / \mathrm{ml}$; G-CSF, $5 \mathrm{ng} / \mathrm{ml}$ + bFGF, $0.1 \mathrm{ng}$; G-CSF, $5 \mathrm{ng} / \mathrm{ml}$

+ bFGF, $1 \mathrm{ng} / \mathrm{ml}$; G-CSF, $0.05 \mathrm{ng} / \mathrm{ml}+$ bFGF, $1 \mathrm{ng} / \mathrm{ml}$ vs. G-CSF, $5 \mathrm{ng} / \mathrm{ml}+\mathrm{bFGF}, 1 \mathrm{ng} / \mathrm{ml}$.

washed, and then stimulated with $100 \mathrm{ng} / \mathrm{ml}$ of G-CSF, the wound repair observed after $24 \mathrm{~h}$ was partially blocked (not shown). This suggests that G-CSF-induced repair required both migration and DNA synthesis. Boiled and biologically inactive G-CSF ( $100 \mathrm{ng} / \mathrm{ml}$ ) (8) and IL-3 (up to $100 \mathrm{ng} / \mathrm{ml}$ ) did not induce wound repair, whereas GM-CSF (from $1 \mathrm{ng} / \mathrm{ml}$ to $100 \mathrm{ng} / \mathrm{ml}$ ) did so (not shown). Under the same conditions, bFGF $(5 \mathrm{ng} / \mathrm{ml})$ was also able to induce complete wound repair by $18-24 \mathrm{~h}$ (data not shown).

Cell migration was also quantified by counting the number of HUVEC that had moved after $6 \mathrm{~h}$ into the denuded area. The migration was quantified by observing cells with a grid 
Table II. Effect of Various Molecules with CSF Activity on HUVEC

\begin{tabular}{|c|c|c|c|c|}
\hline Cytokine & PAF & PCA & Proliferation & Migration \\
\hline & pmol/10s cells & $m U / 10^{5}$ cells & $10^{4}$ cells & $\begin{array}{l}\text { Cells in } \\
\text { six fields }\end{array}$ \\
\hline None & $0.2 \pm 0.1$ & $6 \pm 2$ & $24.3 \pm 0.9$ & $21 \pm 4$ \\
\hline $\mathrm{G}-\mathrm{CSF}(100 \mathrm{ng} / \mathrm{ml})$ & $0.4 \pm 0.2$ & $9 \pm 3$ & $39.9 \pm 1.4$ & $79 \pm 4$ \\
\hline GM-CSF $(100 \mathrm{ng} / \mathrm{ml})$ & $0.3 \pm 0.1$ & $11 \pm 5$ & $34.1 \pm 2.3$ & $69 \pm 4$ \\
\hline IL-1 $(1 \mathrm{ng} / \mathrm{ml})$ & $2.1 \pm 0.4$ & $87 \pm 9$ & $21.3 \pm 1.4$ & $25 \pm 5$ \\
\hline $\mathrm{M}-\mathrm{CSF}(50 \mathrm{ng} / \mathrm{ml})$ & $0.3 \pm 0.4$ & $7 \pm 6$ & $23.4 \pm 3.9$ & $23 \pm 5$ \\
\hline IL-3 $(100 \mathrm{ng} / \mathrm{ml})$ & $0.2 \pm 0.1$ & $10 \pm 2$ & $24.1 \pm 2.2$ & $21 \pm 2$ \\
\hline
\end{tabular}

The various parameters of HUVEC activation were assessed after different times (from 10 min to 4 d) of exposure of cells to G-, GM-CSF, IL-3, and M-CSF. The data presented refer to exposure times at which the appropriate reference cytokine active on each parameter (see Table I) induced a maximal response. Specifically, exposure times were: $6 \mathrm{~h}$ for PAF; $4 \mathrm{~h}$ for PCA; $4 \mathrm{~d}$ for proliferation; and $6 \mathrm{~h}$ for migration. Mean $\pm S D$ of three to six experiments done at least in duplicate.

marked in increments of $100 \mu \mathrm{m}$ (Table III). G- and GM-CSF showed a dose-dependent effect and had an equivalent potency in inducing HUVEC migration. The number of cells migrated in the first, second, and third $100-\mu \mathrm{m}$ segment in the presence of an optimal concentration of G- or GM-CSF is 100-, 80-, and 50 -fold higher than in unstimulated monolayers. Boiling Gand GM-CSF abolished the activity as well as antibodies against G-CSF and GM-CSF. Basic FGF had similar effects, but at lower concentrations than that of active G- and GMCSF. IL-3 and M-CSF were ineffective (Table III).

Modification of HUVEC cytoskeleton induced by $G$ - and $G M-C S F$. Migrating cells undergo shape changes with characteristic cytoskeletal reorganization. Hence, it was of interest to study the cytoskeletal structures of HUVEC exposed to G- and GM-CSF. Upon staining with R-PHD that specifically binds to F-actin, resting HUVEC showed an elaborate array of microfilament bundles of the stress fiber type (Fig. $4 a$ ) and scattered vinculin streaks, which correspond to areas of focal contact of the ventral membrane with the adhesion substratum (Fig. $4 \mathrm{~b}$ ). $1 \mathrm{~h}$ upon G-CSF $(100 \mathrm{ng} / \mathrm{ml})$ or GM-CSF $(100 \mathrm{ng} / \mathrm{ml})$ (not shown), stress fibers partially disappeared (Fig. $4 c$ ), vinculin streaks moved at the cells periphery and to the "tail" (Fig. $4 d$ ) and cells assumed a typical migratory phenotype.

Angiogenic activity of $G-C S F$. In an effort to explore the in vivo relevance of the induction of endothelial cell migration and proliferation by G- and GM-CSF, we studied angiogenesis in the rabbit cornea. For these experiments we used G-CSF since this molecule, unlike GM-CSF, is not species-restricted: human G-CSF is in fact active in vitro and in vivo in rodents (46-48).
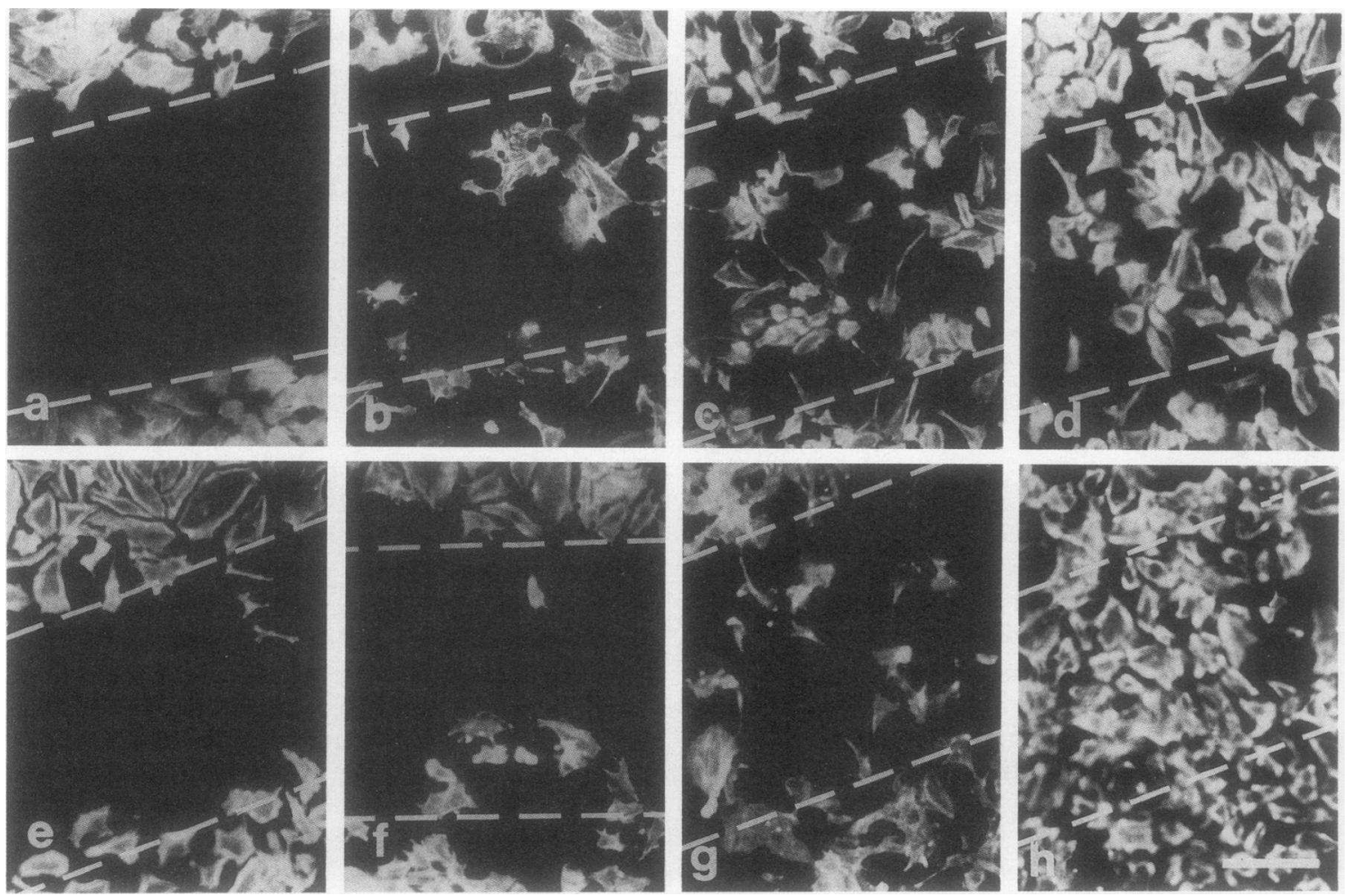

Figure 3. Effect of G-CSF on wound repair of HUVEC monolayers. Confluent stationary HUVEC cultured on glass coverslips coated with human fibronectin $(10 \mu \mathrm{g} / \mathrm{ml})$ were wounded by scratching with a razor blade splinter, cultured for $24 \mathrm{~h}$ in M199 containing $20 \%$ FCS, and treated with $100 \mathrm{ng} / \mathrm{ml} \mathrm{G-CSF}$ for $6(b), 12(c)$, and $24 \mathrm{~h}(d)$, or without G-CSF for $24 \mathrm{~h}(a)$. Coverslips were fixed, permeabilized, and stained with R-PHD at the indicated times as described in Methods. The administration of G-CSF induces a shift in cell phenotype from stationary (stress fiber rich) to migratory; cells start to migrate and progressively fill the wound gap in about $24 \mathrm{~h}(d)$, while few if any cells migrate from the wound edges (indicated in all panels by dashed lines) in the same period of time without G-CSF $(a)$. The effect of G-CSF is dose-dependent since the number of cells migrating into the wound gap in $24 \mathrm{~h}$ was almost negligible with $0.1 \mathrm{ng} / \mathrm{ml}(e)$ and increased with $1 \mathrm{ng} / \mathrm{ml}(f), 10 \mathrm{ng} / \mathrm{ml}$ $(g)$, and $100 \mathrm{ng} / \mathrm{ml}$, to reach nearly complete repair $(h)$. Bar denotes $28 \mu \mathrm{m}$. 
Table III. Quantitative Analysis of Wound Repair by $G-C S F$ and $G M-C S F$

\begin{tabular}{|c|c|c|c|}
\hline & \multicolumn{3}{|c|}{$100 \mu \mathrm{m}$ segment } \\
\hline & $\mathbf{I}$ & II & III \\
\hline & \multicolumn{3}{|c|}{ No. cells/microscope field } \\
\hline Control & $6 \pm 2$ & 0 & 0 \\
\hline G-CSF (1 ng/ml) & $7 \pm 2$ & 0 & 0 \\
\hline G-CSF $(10 \mathrm{ng} / \mathrm{ml})$ & $45 \pm 12$ & $27 \pm 8$ & $12 \pm 4$ \\
\hline G-CSF (100 ng/ml) & $113 \pm 27$ & $86 \pm 11$ & $51 \pm 17$ \\
\hline Boiled G-CSF (100 ng/ml) & $10 \pm 3$ & 0 & 0 \\
\hline G-CSF $(100 \mathrm{ng} / \mathrm{ml})+$ anti-G-CSF & $8 \pm 2$ & 0 & 0 \\
\hline G-CSF+ irrelevant IgG & $145 \pm 20$ & $81 \pm 18$ & $54 \pm 12$ \\
\hline GM-CSF (1 ng/ml) & $11 \pm 4$ & 0 & 0 \\
\hline GM-CSF (10 ng/ml) & $65 \pm 21$ & $34 \pm 17$ & $14 \pm 3$ \\
\hline GM-CSF (100 ng/ml) & $126 \pm 18$ & $90 \pm 19$ & $61 \pm 20$ \\
\hline Boiled GM-CSF $(100 \mathrm{ng} / \mathrm{ml})$ & $9 \pm 2$ & 0 & 0 \\
\hline GM-CSF $(100 \mathrm{ng} / \mathrm{ml})$ +anti-GM-CSF & $4 \pm 7$ & 0 & 0 \\
\hline GM-CSF $(100 \mathrm{ng} / \mathrm{ml})+$ irrelevant IgG & $118 \pm 31$ & $88 \pm 10$ & $69 \pm 15$ \\
\hline IL-3 $(100 \mathrm{ng} / \mathrm{ml})$ & $8 \pm 1$ & 0 & 0 \\
\hline $\mathrm{M}-\mathrm{CSF}(50 \mathrm{ng} / \mathrm{ml})$ & $5 \pm 3$ & 0 & 0 \\
\hline bFGF $0.1 \mathrm{ng} / \mathrm{ml}$ & $16 \pm 3$ & 0 & 0 \\
\hline $\mathrm{bFGF} 1 \mathrm{ng} / \mathrm{ml}$ & $39 \pm 4$ & $46 \pm 5$ & $28 \pm 4$ \\
\hline bFGF $5 \mathrm{ng} / \mathrm{ml}$ & $146 \pm 12$ & $84 \pm 7$ & $71 \pm 10$ \\
\hline
\end{tabular}

Wound repair was quantitated by counting cells at $\times 100$ with a grid marked in increments of $100 \mu \mathrm{m}$ from the original mark made by the razor blade considered as origin. The data are the mean \pm SD of cells counted in six individual fields in one coded experiment. Three similar experiments have been performed with similar results. Mean \pm SD of six determinations.

G-CSF and GM-CSF were incubated overnight at $4^{\circ} \mathrm{C}$ with $160 \mu \mathrm{g}$ of mouse anti-human G-CSF monoclonal antibody (75A, neutralizing activity: $33 \mathrm{U} / \mu \mathrm{g}$ ) and a polyclonal rabbit anti-human GM-CSF (1:500 dilution) (a 1:1,000 dilution neutralized $500 \mathrm{U}$ ), respectively.
Table IV. Angiogenic Activity of G-CSF

\begin{tabular}{|c|c|c|c|}
\hline Corneal implant & $\begin{array}{c}\text { No. of } \\
\text { implants }\end{array}$ & $\begin{array}{l}\text { No. positive } \\
\text { implants }\end{array}$ & Score* \\
\hline ng/pellet & & & Range \\
\hline \multicolumn{4}{|c|}{ One pellet implant $t^{\ddagger}$} \\
\hline Elvax-40 & 10 & 0 & 0 \\
\hline \multicolumn{4}{|l|}{ G-CSF } \\
\hline $10 \mathrm{ng}$ & 9 & 1 & 1 \\
\hline $50 \mathrm{ng}$ & 12 & 6 & $2-3$ \\
\hline $100 \mathrm{ng}$ & 9 & 5 & $2-3$ \\
\hline \multicolumn{4}{|l|}{ Boiled G-CSF } \\
\hline $50 \mathrm{ng}$ & 9 & 1 & 2 \\
\hline $100 \mathrm{ng}$ & 6 & 1 & 1 \\
\hline \multicolumn{4}{|l|}{ bFGF } \\
\hline $1 \mathrm{ng}$ & 10 & 2 & 1 \\
\hline $5 \mathrm{ng}$ & 10 & 3 & 1 \\
\hline $10 \mathrm{ng}$ & 12 & 3 & $1-2$ \\
\hline $50 \mathrm{ng}$ & 12 & 10 & 4 \\
\hline \multicolumn{4}{|c|}{ Two pellet implants ${ }^{8}$} \\
\hline G-CSF, $50 \mathrm{ng}+$ Elvax & 11 & 5 & $2-3$ \\
\hline bFGF, $10 \mathrm{ng}+$ Elvax & 11 & 2 & 1 \\
\hline G-CSF, $50 \mathrm{ng}+\mathrm{bFGF}, 10 \mathrm{ng}$ & 11 & 9 & 4 \\
\hline Boiled G-CSF, $50 \mathrm{ng}+\mathrm{FGF}, 10 \mathrm{ng}$ & 12 & 3 & $1-2$ \\
\hline
\end{tabular}

* An arbitrary score was designed as follows: 0 , no vessel growth; 1 , equivocal vessel growth from the limbus to $0.6 \mathrm{~mm}$ over the limbus; 2 , evident new vessel formation extending midway to the corneal pocket; 3, prominent new vessel formation reaching the corneal pocket; 4 , extensive neovascularization extending into the corneal pocket and surrounding the implant.

* The data reported were obtained by implanting one pellet in one pocket.

$\S$ The data reported were obtained by implanting two separate pellets into two adjacent pockets.

versus implants containing Elvax alone by Fisher exact test). Increasing the dose tested $(100 \mathrm{ng} /$ pellet $)$ did not modify the angiogenic response. G-CSF at a concentration of $10 \mathrm{ng} /$ pellet was almost devoid of any angiogenic activity ( 1 positive out of 9) (Table IV). The newly formed vessel network consisted of
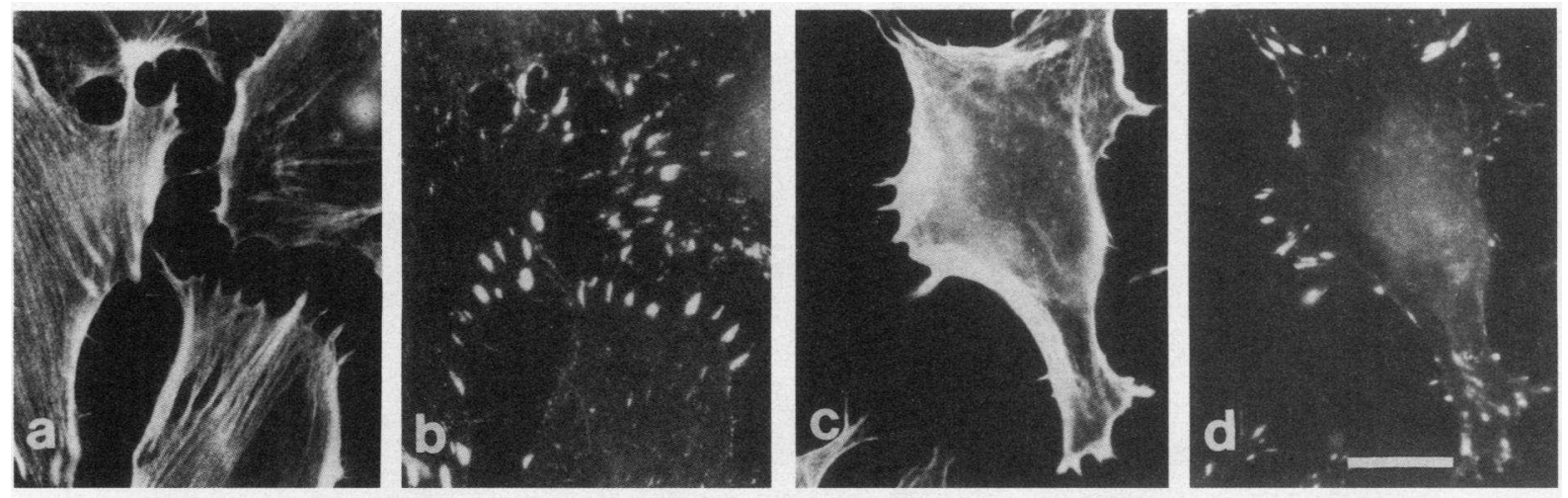

Figure 4. Effect of G-CSF on cytoskeletal structures of HUVEC during the repair of the wound gap. HUVEC monolayers were processed as detailed in the legend to Fig. 3 after $1 \mathrm{~h}$ stimulation. Without G-GSF, cells at wound edges mostly show stress fibers $(a)$ and numerous vinculin-containing adhesion plaques located at stress fiber endings $(b)$. Upon exposure to G-CSF (100 ng/ml), cells acquire a migratory phenotype with fewer stress fibers $(c)$ and vinculin streaks mostly located at the cell periphery and in the tail $(d)$. Bar denotes $5 \mu \mathrm{m}$. 

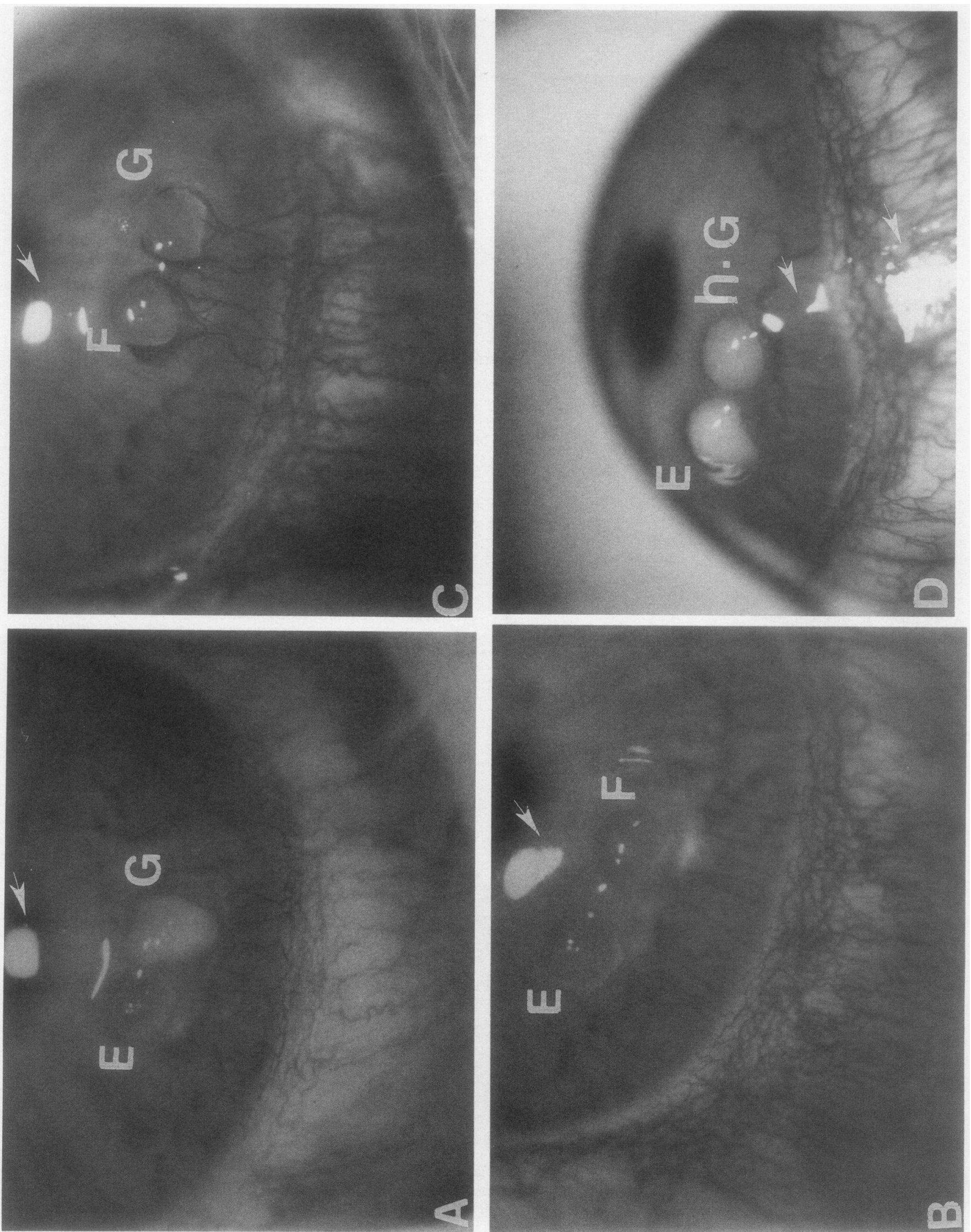

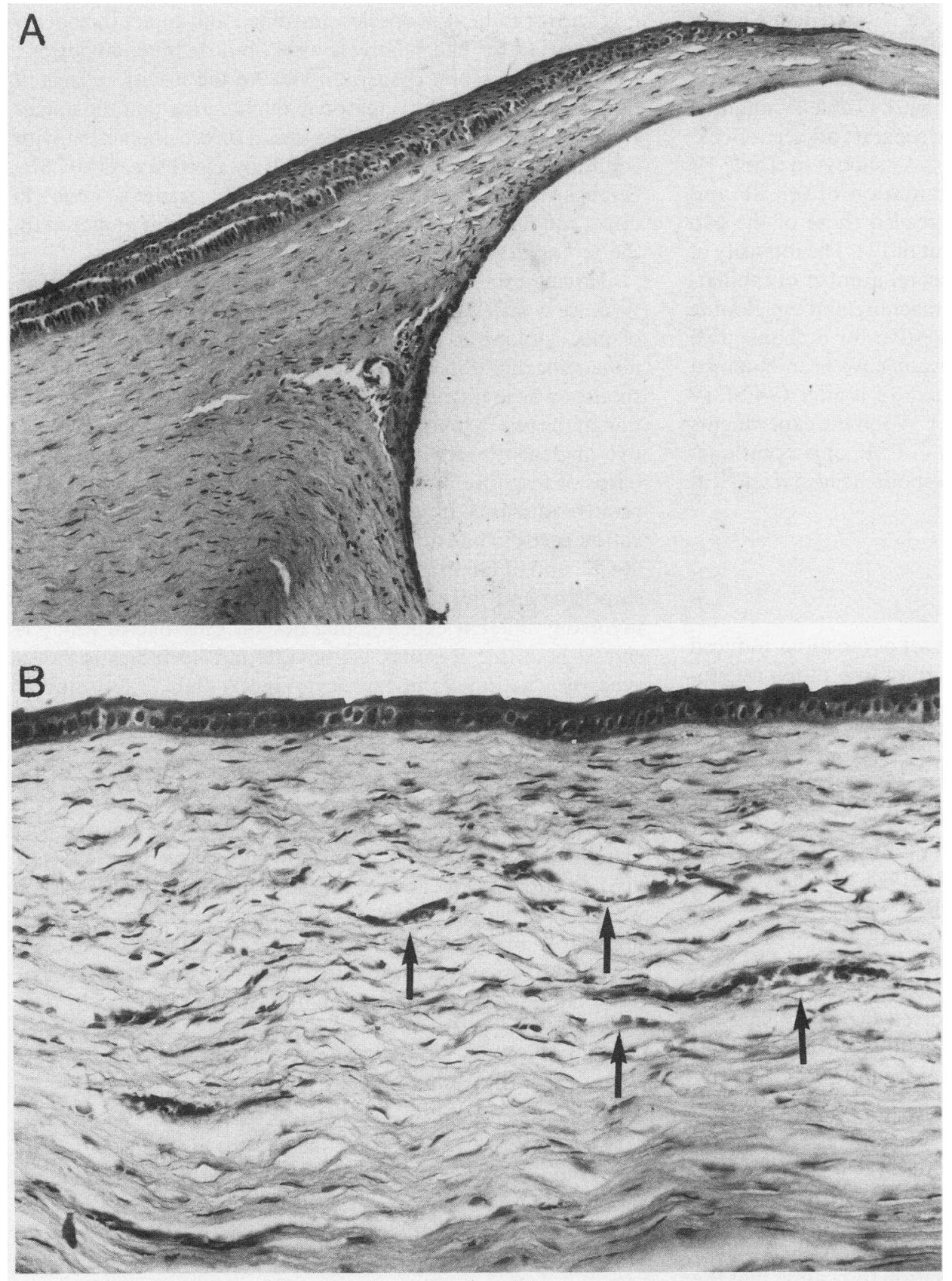

Figure 6. Histology (hematoxylin and eosin) of rabbit corneas removed 12 $\mathrm{d}$ after the implant of G-CSF $(50 \mathrm{ng})$. (A) Section $(7 \mu \mathrm{m})$ of the pocket bearing the Elvax pellet releasing GCSF. The pellet was removed and the surrounding tissue appeared as in $B$ $(\times 100)$. $(B)$ Section $(7 \mu \mathrm{m})$ of the rabbit cornea removed from the area between the pellet and the limbus. Note the cross section of several capillaries (arrows) and the complete absence of inflammatory-type infiltrate to establish that angiogenesis was not due to formation of a granulation tissue. $(\times 200$. $)$ $\sim 30-40$ capillaries that reached the pellet implant by day 8 and did not further progress (Fig. $5 a$ and Fig. 6). Histological sections of corneal specimens obtained $12 \mathrm{~d}$ after the implant showed the presence of several well-defined capillaries (Fig. 6 $b$ ). No macroscopic or microscopic signs of an accompanying inflammatory reaction were observed as stated by persistence of corneal transparency (Fig. 5) and by the absence of any inflammatory infiltrate in the histological sections (Fig. 6).
When G-CSF was heat inactivated, its angiogenic activity was consistently reduced (Table IV). Implanted bFGF produced a consistent angiogenic response (80-100 capillaries enveloping the implant by day 12) at a dose of $50 \mathrm{ng} / \mathrm{pellet}$ (Table IV). At lower doses, only few implants hinted an angiogenic response which, at best, produced 5-10 capillaries budding from the limbus and never progressing over half the way to reach the implanted pellet (Table IV and Fig. $5 b$ ).

Figure 5. Effect of G-CSF on angiogenesis. G-CSF ( $50 \mathrm{ng} /$ pellet) induced the formation of slowly progressing newly formed capillaries into the cornea stroma $(a)$. When G-CSF was assayed with a nonangiogenic dose of bFGF ( $10 \mathrm{ng} / \mathrm{pellet})(b)$, cornea neovascularization appeared more consistent and efficient in terms of vessel number and growth velocity $(c)$. Heat inactivation of G-CSF produced loss of angiogenic activity. The pictures represent implant of Elvax-40 pellets into two separate pockets. In panels A and B, G-CSF and bFGF were assayed in the presence of a control pellet. All photographs $(\times 18)$ were taken at day 12 from the surgical implants through a slit lamp stereomicroscope (Olympus Corp. of America, New Hyde Park, NY). Arrows indicate a white spot produced by light reflex. G, G-CSF; F, bFGF; hG, heat-inactivated G-CSF; E, Elvax pellet. 
In a second set of experiments we wanted to examine whether G-CSF acted in concert with bFGF in inducing neovascularization. Implanted bFGF was used at doses unable per se to elicit a fully competent vascular network (Table IV and Fig. $5 \mathrm{~b}$ ). The two cytokines were placed in separate adjacent pockets to avoid any physical interactions. As shown in Table IV and in Fig. $5 c$, the combined implantation of G-CSF and bFGF resulted in a response that exceeded those of the two cytokines alone ( 8 positive implants out of 11 ). The intensity of the angiogenic response (in terms of score, number of capillaries [60-80] and growth rate [vessels reaching and enveloping the pellets by $10 \mathrm{~d}$ ]) was highly suggestive for a cooperative effect of the two cytokines. Similar results have been obtained when addition of bFGF was implanted $72 \mathrm{~h}$ after G-CSF ( 9 positive over 11 implants) (not shown). When the experiments were performed with heat-inactivated G-CSF, only occasional implants showed a weak angiogenic response (Fig. $5 d$ and Table IV).

\section{Discussion}

The results presented here identify the set of functions induced in HUVEC by G- and GM-CSF in relation to prototypic cytokines active on this cell type. They confirm and extend our original observations that G- and GM-CSF induced migration and proliferation of endothelial cells $(8,10)$. Unlike appropriate reference cytokines (IL- $1 \alpha / \mathrm{TNF} \alpha$, IFN- $\gamma$ ), G- and GMCSF did not modulate endothelial cell functions related to hemostasis-thrombosis (synthesis of PCA and PAF), inflammation (expression of ELAM-1 and synthesis of PAF), and accessory function (HLA-Dr). In comparison to bFGF, G- and GM-CSF induced lower maximal proliferation of HUVEC, whereas migration was of the same order of magnitude.

The proliferation and migration assays used routinely in this and previous studies $(8,10)$, involved the use of sparsely seeded HUVEC. Gerlach et al. (45) recently reported substantial differences in the response (thrombomodulin activity, PCA, and barrier function) of sparse versus monolayer HUVEC to TNF. We therefore examined the capacity of G- and GM-CSF to stimulate repair of mechanically wounded HUVEC monolayers, a situation possibly more similar to in vivo conditions. The two CSF molecules stimulated wound repair by HUVEC. This phenomenon was partially inhibited by mitomycin $\mathrm{C}$, an inhibitor of cell proliferation indicating that the wound repair induced by G- and GM-CSF is due to both migration and growth of HUVEC. This result is in agreement with our previous data showing that maximal motility in the Boyden chamber assay was observed after $6 \mathrm{~h}(8)$, and maximal uptake of thymidine after $12 \mathrm{~h}(8)$. Furthermore, previous studies (49) have shown that endothelium, at the leading edge of a wound, began DNA synthesis at $\sim 8-10 \mathrm{~h}$ and reached maximum at $20 \mathrm{~h}$. The monolayer wound system also allowed an analysis of changes in the cytoskeleton of HUVEC exposed to G- and GM-CSF. HUVEC treated with G- or GM-CSF displayed a motile phenotype, characterized by leading edges and often a prominent tail, loss of their normal network of stress fibers and of vinculin streaks.

Having established that G- and GM-CSF induced endothelial cell migration and proliferation under different in vitro conditions, it was important to investigate the in vivo relevance of these observations. G-CSF was used for these studies because it is known to be non-species-restricted and to act in rodents (46-48). G-CSF had relatively weak, but definite, angiogenic activity in the rabbit cornea. In view of the in vitro effects of G-CSF on HUVEC, it is reasonable to assume that the angiogenic effect of G-CSF in vivo reflects a direct interaction with endothelial cells. Thus, G-CSF (and, by inference, GM-CSF) belongs to the group of factors that induce angiogenesis via direct modulation of endothelial cell locomotion and growth, the prototypes of which are FGFs $(32,33)$.

Having established that G-CSF has angiogenic activity in vivo, we wanted to obtain initial indications as to the capacity of this cytokine to act in concert with bFGF. By combining nonangiogenic doses of bFGF with G-CSF, we observed responses whose intensity is suggestive of a cooperative interaction of the two cytokine in inducing angiogenesis. The cooperative angiogenic activity of G-CSF and bFGF was evident in terms of response intensity (number of capillaries, number of positive implants, time to reach the pellets). This initial observation needs to be extended. However, the cooperative effect of $\mathrm{G}-\mathrm{CSF}$ and bFGF in inducing in vivo angiogenesis is somewhat surprising and intriguing. In fact, in vitro, in spite of efforts involving different experimental designs only one of which is shown here (see Results), we have found no indication of a synergistic action of these two cytokines on HUVEC proliferation and migration. At best, an additive effect was observed. In vivo angiogenesis occurs as the end point of complex interactions between many events involving the remodeling of the extracellular matrix and the release of several "factors" (12, 50). This apparent paradox of a combination of cytokines acting directly on endothelial cells, showing a cooperative effect in vivo, but not in vitro, adds to the list of factors or conditions for which in vitro modulation of proliferation and migration is not necessarily predictive of in vivo effects on angiogenesis (12). Possible explanations for this partial discrepancy in the capacity of G-CSF to act in concert with bFGF in vitro and in vivo could involve a different biology of microvascular endothelium versus HUVEC or effects of G-CSF on passing neutrophils.

Various cell types, including activated immunocompetent cells, fibroblasts, and endothelial cells themselves, can produce G- and GM-CSF (1-3). Thus, locally produced G- and GMCSF could be part of the regulatory network of neovascularization and, in bone marrow, contribute to the maintenance of the hematopoietic microenvironment, of which endothelial cells are one important component.

\section{Acknowledgments}

We thank Dr. P. Gullino, Dipartimento di Scienze Biomediche e Oncologia Umana, Università di Torino, for advice and criticism and for the light microscopy studies done on corneal explants, and Dr. E. Dejana, Istituto di Ricerche Farmacologiche "Mario Negri" for helpful discussions.

This work was supported by Consiglio Nazionale delle Ricerche (CNR), special project "Biotecnologie e Biostrumentazione," by Ministero dell'Università e della Ricerca Scientifica e Tecnologica (MURST), and by Associazione Italiana per la Ricerca sul Cancro (AIRC).

\section{References}

1. Clark, S. C., and R. Kamen. 1987. The human hematopoietic colony-stimulating factors. Science (Wash. DC). 236:1229-1237.

2. Sieff, C. A. 1987. Hematopoietic growth factors. J. Clin. Invest. 79:15491557. 
3. Metcalf, D. 1989. The molecular control of cell division, differentiation commitment and maturation in haematopietic cells. Nature (Lond.). 339:27-30.

4. Dedhar, S., L. Gaboury, P. Galloway, and C. Eaves. 1988. Human granulocyte-macrophage colony-stimulating factor is a growth factor active on a variety of cell types of nonhemopoietic origin. Proc. Natl. Acad. Sci. USA. 85:92539257.

5. Cocita Baldwin, G., J. C. Gasson, S. E. Kaufman, S. G. Quan, R. E. Williams, B. R. Avalos, A. F. Gazdar, D. W. Golde, and J. F. DiPersio. 1989. Nonhematopoietic tumor cells express functional GM-CSF receptors. Blood. 73:10331037.

6. Berdel, W. E., S. Danhauser-Riedl, G. Steinhauser, and E. F. Winton. 1989. Various human hematopoietic growth factors (Interleukin-3, GM-CSF, G-CSF) stimulate clonal growth of nonhematopoietic tumor cells. Blood. 73:80-83.

7. Hancock, G. E., G. Kaplan, and Z. A. Cohn. 1988. Keratinocyte growth regulation by the products of immune cells. J. Exp. Med. 168:1395-1402

8. Bussolino, F., J. M. Wang, P. Defilippi, F. Turrini, F. Sanavio, C. J. Edgell, M. Aglietta, P. Arese, and A. Mantovani. 1989. Granulocyte- and granulocytemacrophage-colony stimulating factors induce human endothelial cells to migrate and proliferate. Nature (Lond.). 337:471-473.

9. Gearing, D. P., J. A. King, N. M. Gough, and N. A. Nicola. 1989. Expression cloning of a receptor for human granulocyte-macrophage colony-stimulating factor. EMBO (Eur. Mol. Biol. Organ.) J. 8:3667-3676.

10. Bussolino, F., J. M. Wang, F. Turrini, D. Alessi, D. Ghigo, C. Costamagna, G. Pescarmona, A. Mantovani, and A. Bosia. 1989. Stimulation of the $\mathrm{Na}^{+} / \mathrm{H}^{+}$exchanger in human endothelial cells activated by granulocyte- and granulocyte-macrophage-colony-stimulating factor. Evidence for a role in proliferation and migration. J. Biol. Chem. 264:18284-18287.

11. Kojima, S., H. Tadenuma, Y. Inada, and Y. Saito. 1989. Enhancement of plasminogen activator activity in cultured endothelial cells by granulocyte colony-stimulating factor. J. Cell. Physiol. 138:192-196.

12. Folkman, J., and M. Klagsbrun. 1987. Angiogenic factors. Science (Wash. DC). 236:442-447.

13. Cotran, R. S. 1987. New roles for the endothelium in inflammation and immunity. Am. J. Pathol. 129:407-414.

14. Pober, J. S. 1988. Cytokine-mediated activation of vascular endothelium. Am. J. Pathol. 133:426-433.

15. Mantovani, A., and E. Dejana. 1989. Cytokines as communication signals between leukocytes and endothelial cells. Immunol. Today. 10:370-375.

16. Bevilacqua, M. P., J. S. Pober, G. R. Majeau, R. S. Cotran, and M. A. Gimbrone, Jr. 1984. Interleukin-1 (IL-1) induces biosynthesis and cell surface expression of procoagulant activity in human vascular endothelial cells. $J$. Exp. Med. 160:618-623.

17. Dejana, E., F. Breviario, A. Erroi, F. Bussolino, L. Mussoni, M. Gramse, G. Pintucci, B. Casali, C. A. Dinarello, J. Van Damme, and A. Mantovani. 1987. Modulation of endothelial cell function by different molecular species of interleukin 1. Blood. 69:695-699.

18. Bevilacqua, M. P., J. S. Pober, G. R. Majeau, W. Fiers, R. S. Cotran, and M. A. Gimbrone, Jr. 1986. Recombinant tumor necrosis factor induces procoagulant activity in cultured human endothelial cells: characterization and comparison with the actions of interleukin 1. Proc. Natl. Acad. Sci. USA. 83:4533-4537.

19. Naworth, P. P., C. T. Handley, C. Esmon, and D. M. Stern. 1986. Interleukin 1 induced endothelial cell procoagulant activity while suppressing cell surface anticoagulant activity. Proc. Natl. Acad. Sci. USA. 83:3460-3464.

20. Rossi, V., F. Breviario, P. Ghezzi, E. Dejana, and A. Mantovani. 1985 Prostacyclin synthesis induced in vascular cells by interleukin-1. Science (Wash. DC). 229:174-177.

21. Kawakami, M., S. Hishibashi, H. Ogawa, T. Murase, F. Takaku, and S Shibata. 1986. Cachectin/TNF as well as interleukin-1 induces prostacyclin synthesis in cultured vascular endothelial cells. Biochem. Biophys. Res. Commun. 141:482-488.

22. Bussolino, F., F. Breviario, C. Tetta, M. Aglietta, A. Mantovani, and E. Dejana. 1986. Interleukin 1 stimulates platelet-activating factor production in cultured human endothelial cells. J. Clin. Invest. 77:2027-2033.

23. Camussi, G., F. Bussolino, G. Salvidio, and C. Baglioni. 1987. Tumor necrosis factor/cachectin stimulates peritoneal macrophages, polymorphonuclear neutrophils, and vascular endothelial cells to synthesize and release plateletactivating factor. J. Exp. Med. 166:1390-1404.

24. Schleef, R. S., M. P. Bevilacqua, M. Sawdey, M. A. Gimbrone, Jr., and D. J. Loskutoff. 1988. Cytokine activation of vascular endothelium. Effects on tissue-type plasminogen activator and type 1 plasminogen activator inhibitor. $J$. Biol. Chem. 263:5797-5803.

25. Nawroth, P. P., and D. M. Stern. 1986. Modulation of endothelial cell hemostatic properties by tumor necrosis factor. J. Exp. Med. 163:740-745.

26. Bevilacqua, M. P., J. S. Pober, D. L. Mendrick, R. S. Cotran, and M. A. Gimbrone, Jr. 1987. Identification of an inducible endothelial-leukocyte adhesion molecule. Proc. Natl. Acad. Sci. USA. 84:9238-9242.

27. Bevilacqua, M. P., S. Stengelin, M. A. Gimbrone, Jr., and B. Seed. 1989. Endothelial leukocyte adhesion molecule 1: an inducible receptor for neutrophils related to complement regulatory proteins and lectins. Science (Wash. DC). 243:1160-1164.
28. Pober, J. S., M. A. Gimbrone, Jr., L. A. Lapierre, D. L. Mendrick, W. Fiers, R. Rothlein, and T. A. Springer. 1986. Overlapping pattern of activation of human endothelial cells by interleukin 1, tumor necrosis factor and immune interferon. J. Immunol. 137:1893-1896.

29. Rice, G. R., and M. P. Bevilacqua. 1989. An inducible cell surface glycoprotein mediates melanoma adhesion. Science (Wash. DC). 246:1303-1306.

30. Pober, J. S., M. A. Gimbrone, Jr., R. S. Cotran, C. S. Reiss, S. J. Burakoff, W. Fiers, and K. A. Ault. 1983. Ia expression by vascular endothelium is inducible by activated $T$ cells and by human $\gamma$ interferon. J. Exp. Med. 157:1339-1353.

31. Collins, T., A. J. Korman, C. T. Wake, J. M. Boss, D. J. Kappes, W. Fiers, K. A. Adult, M. A. Gimbrone, Jr., J. L. Strominger, and J. S. Pober. 1984 Immune interferon activates multiple class II major histocompatibility complex antigens and the associated invariant chain gene in human endothelial cells and dermal fibroblasts. Proc. Natl. Acad. Sci. USA. 81:4917-49921.

32. Gospodarowicz, D., N. Ferrara, L. Schweigerer, and G. Neufeld. 1987. Structural characterization and biological functions of fibroblast growth factor Endocr. Rev. 8:95-114.

33. Rifkin, D. E., and D. Moscatelli. 1989. Recent developments in the cell biology of basic fibroblast growth factor. J. Cell Biol. 109:1-6.

34. Müller, G., J. Behrens, U. Nussbaumer, P. Bohlen, and W. Birchmeier. 1987. Inhibitory action of transforming growth factor on endothelial cells. Proc Natl. Acad. Sci. USA. 84:5600-5604.

35. Schreiber, A. B., M. E. Winkler, and R. Derynck. 1986. Transforming growth factor-alpha: a more potent angiogenic mediator than epidermal growth factor. Science (Wash. DC). 232:1250-1253.

36. Takehara, K., E. C. LeRoy, and G. R. Grotendorst. 1987. TGF-inhibition of endothelial cell proliferation: alteration of EFG binding and EGF-induced growth-regulatory (competence) gene expression. Cell. 49:415-422.

37. Falk, W., R. H. Goodwin, Jr., and E. J. Leonard. 1980. A 48-well microchemotaxis assembly for rapid and accurate measurement of leukocyte migration. J. Immunol. Methods. 33:239-247.

38. Dejana, E., L. R. Languino, N. Polentarutti, G. Balconi, J. J. Ryckewaert, M. J. Larrieu, M. B. Donati, A. Mantovani, and G. Marguerie. 1985. Interaction between fibrinogen and cultured endothelial cells. Induction of migration and specific binding. J. Clin. Invest. 75:11-18.

39. Bussolino, F., G. Camussi, M. Aglietta, P. Braquet, A. Bosia, G. Pescarmona, F. Sanavio, N. D'Urso, and P. C. Marchisio. 1987. Human endothelial cells are target for platelet activating factor. I. Platelet-activating factor induces changes in cytoskeleton structures. $J$. Immunol. 139:2439-2446.

40. Sato, Y., and D. B. Rifkin. 1989. Inhibition of endothelial cell movement by pericytes and smooth muscle cells: activation of a latent transforming growth factor- $\beta 1$-like molecule by plasmin during co-culture. J. Cell Biol. 109:309-315.

41. Bussolino, F., F. Gremo, C. Tetta, G. Pescarmona, and G. Camussi. 1986. Platelet activating factor production by chick retina. J. Biol. Chem. 261:1650216509.

42. Malavasi, F., C. Tetta, A. Funaro, G. Bellone, E. Ferrero, A. Colli Franzone, P. Dellabona, R. Rusci, L. Matera, G. Camussi, and F. Caligaris Cappio. 1986. Fc receptor triggering induces expression of surface activation antigens and release of platelet activating factor in large granular lymphocytes. Proc. Natl. Acad. Sci. USA. 83:2443-2447.

43. Gullino, P. M. 1981. Angiogenesis factor(s). In Handbook of Experimental Pharmacology. Springer-Verlag, Berlin. 57:427-449.

44. Ziche, M., G. Alessandri, and P. M. Gullino. 1989. Gangliosides promote the angiogenic response. Lab. Invest. 61:629-634.

45. Gerlach, H., H. Lieberman, R. Bach, G. Godman, J. Brett, and D. Stern. 1989. Enhanced responsiveness of endothelium in the growing/motile state to tumor necrosis factor/cachectin. J. Exp. Med. 170:913-931.

46. Nagata, S., M. Tsuchiya, S. Asano, Y. Kaziro, T. Yamazaki, O. Yamamoto, Y. Hirata, N. Kubota, M. Oheda, H. Nomura, and M. Ono. 1986. Molecular cloning and expression of cDNA for human granulocyte colony-stimulating factor. Nature (Lond.). 319:415-418.

47. Cohen, A. M., K. M. Zsebo, H. Inoue, D. Hines, T. C. Boone, V. R. Chazin, L. Tsai, T. Ritch, and L. M. Souza. 1987. In vivo stimulation of granulopoiesis by recombinant human granulocyte-colony stimulating factor. Proc. Natl. Acad. Sci. USA. 84:2484-2488.

48. Souza, L. M., T. C. Boone, J. Gabrilove, P. H. Lai, K. M. Zsebo, D. C. Murdock, V. R. Chazin, J. Bruszewski, H. Lu, K. K. Chen, et al. 1986. Recombinant human granulocyte colony-stimulating factor: effects on normal and leukemic myeloid cells. Science (Wash. DC). 232:61-65.

49. Heimark, R. L., D. R. Twardzik, and S. M. Schwartz. 1986. Inhibition of endothelial regeneration by type-beta transforming growth factor from platelets. Science (Wash. DC). 233:1078-1080.

50. Ingber, D. E., and J. Folkman. 1989. How does extracellular matrix control capillary morphogenesis? Cell. 58:803-805.

51. Prescott, S. M., G. Z. Zimmerman, and T. M. McIntyre. 1984. Human endothelial cells in culture produce platelet activating factor (1-0-alkyl-2-acetylsn-glyceryl-3-phosphorylcholine) when stimulated with thrombin. Proc. Natl. Acad. Sci. USA. 81:3534-3938. 